\title{
Hubungan antara Pengetahuan dan Status Gizi Ibu Hamil dengan Kejadian
} Pre Eklamsia pada Ibu Hamil

\author{
${ }^{1} \mathrm{P}$. Fransiska* \\ ${ }^{1}$ Program Studi Diploma III Kebidanan, Akademi Kebidanan Rangga Husada Prabumulih \\ Email : preceliafransiska5@gmail.com
}

Kata kunci :

Pengetahuan,

Status Gizi,

Pre Eklamsia.

Keywords :

Knowledge,

Nutritional Status,

Pre-Eclampsia.

Info Artikel:

Tanggal dikirim:

23 Maret 2020

Tanggal direvisi:

16 Mei 2020

Tanggal diterima :

6 Juni 2020

DOI Artikel:

10.33862/citradelima.

v4i1.100

Halaman: 22 - 27

\begin{abstract}
Abstrak
Pre eklamsia merupakan penyakit yang ditandai dengan adanya hipertensi, proteinuria dan edema yang ditimbulkan selama kehamilan atau sampai 48 jam postpartum. Tujuan dari penelitian ini adalah untuk mengetahui hubungan antara pengetahuan dan status gizi ibu hamil dengan kejadian pre eklamsia pada ibu hamil di Puskesmas Pasar Kota Prabumulih tahun 2019. Metode Penelitian ini menggunakan Survey Analitik dengan menggunakan pendekatan Cross Sectional. Populasi penelitian ini yaitu ibu hamil yang mengalami pre eklamsia di Puskesmas Pasar Kota Prabumulih. Metode pengambilan sampel penelitian ini dengan metode accidental sampling yaitu 58 responden. Hasil penelitian berdasarkan dari analisa univariat diketahui bahwa dari 58 responden didapatkan bahwa responden yang berpengetahuan baik sebanyak 36 responden $(62,1 \%)$, responden yang berpengetahuan cukup baik sebanyak 20 responden $(34,5 \%)$ dan responden yang berpengetahuan kurang baik sebanyak 2 responden $(3,4 \%)$. Berdasarkan status gizi diketahui bahwa dari 58 responden didapatkan bahwa responden yang mengalami status gizi baik sebanyak 29 responden $(50,0 \%)$ dan responden yang mengalami status gizi buruk sebanyak 29 responden $(50,0 \%)$. Analisa Bivariat menunjukkan Pengetahuan mempunyai hubungan yang bermakna dengan pre eklamsia ( $p$ value 0,006 ) dan Status Gizi mempunyai hubungan yang bermakna dengan kejadian pre eklamsia ( $p$ value 0,000 ). Simpulan dari penelitian ini ada hubungan antara pengetahuan dan status gizi ibu hamil dengan kejadian pre eklamsia pada ibu hamil di Puskesmas Pasar Kota Prabumulih tahun 2019.
\end{abstract}

\section{Relationship between Knowledge and Status of Nutrition of Pregnant Women with the Event of Eklamsia Prevention in Pregnant Women}

\section{Abstract}

Pre eclamsia every pregnant women Indonesia is prone to hypertension, wich is caused for 48 hours,during preganancy. The purpose this study was to determine is relationship between knowledge, and nutritional status the pregnant women with the incidence of preeclampsia, The women pregnant in Prabumulih Country Health Center in 2019. This study uses analytical survey using the cross sectional approach. The population of this were pregnant women who had preeclampsia at Prabumulih country, Health Center. This method take with by doing a test on pregnant women,from the results of research and analysis univariately, from 58 people with detail,36 (62,1\%) people with good knowledge, and $20(34,5 \%)$ people not good. From the results above to $29(50 \%)$ people well also nutrished are, and 29 people nutrition have poor. Bivariate analysis showed that Knowledge had a significant relationship with pre-eclampsia ( $p$ value 0.006 ) and Nutritional Status had a significant relationship with the incidence of pre-eclampsia $(p$ value 0.006). The conclusion of this study is that there is a relationship between knowledge and nutritional status of pregnant women with the incidence of pre-eclampsia in pregnant women in the Prabumulih Coutry Health Center 2019. 


\section{PENDAHULUAN}

Pre eklamsia adalah tekanan darah tinggi pada ibu hamil dan kelebihan kadar protein dalam urine (proteinuria). Namun, tekanan darah tinggi (biasanya di atas 130/90, normalnya 120/80) baru disebut pre eklamsia bila usia kehamilan sudah menginjak 20 minggu ke atas (Shafira, 2014).

Salah satu penyebab angka kematian ibu yaitu Pre eklamsia Berat adalah timbulnya hipertensi disertai proteinuria dan oedema akibat kehamilan setelah usia kehamilan 20 minggu atau segera setelah persalinan (Manuaba, 2012). Pre eklamsia Berat merupakan kesatuan penyakit yang langsung disebabkan oleh kehamilan, sebab terjadinya masih belum jelas. Setelah perdarahan dan infeksi, pre eklamsia dan eklamsia merupakan penyebab kematian maternal dan perinatal paling penting dalam ilmu kebidanan. Pre-eklamsi dikatakan berat jika tekanan darah ibu mencapai $<140 / 110$ mmhg.

Menurut Sustainable Development Goals (SDGs) angka kematian ibu di Indonesia masih cukup tinggi yaitu 267 per 100.000 kelahiran hidup. Berbeda dengan banyak Negara lain. Tertinggalnya Indonesia dalam pencapaian AKI ini juga menunjukkan perbedaan dengan posisi negara lain termasuk di sesama kawasan ASEAN (Fotarisman, 2015).

Angka kematian ibu di Indonesia dihitung berdasarkan data dari Survey Demografi dan Kesehatan Indonesia (SDKI) dan sensus penduduk. Menurut data dari SDKI angka kematian ibu meningkat menjadi 359 per 100.000 kelahiran hidup pada tahun 2015. Angka Kematian Ibu (AKI) ini merupakan yang tertinggi dibandingkan dengan angka kematian di Negara ASEAN lainnya (Roffihin, 2014).

Kematian ibu menunjukkan lingkup yang luas, tidak hanya terkait dengan kematian yang terjadi pada saat proses persalinan, tetapi juga mencakup kematian ibu dalam masa kehamilan dan masa nifas. Kemataian ibu di Indonesia masih didominasi oleh tigas penyebab utama yaitu perdarahan, hipertensi dalam kehamilan (HDK) berupa pre eklamsi dan eklamsia dan penyakit infeksi, lebih dari 25\% kematian ibu di indonesia pada tahun 2013 disebabkan oleh HDK. Proporsi kejadian HDK tahun 2010 sebesar 21,5\%, 2011 sebesar 24,7\%, 2012 sebesar 26,9\% dan kembali meningkat pada tahun 2013 sebesar $27,1 \%$.

Preeklamsi adalah gangguan hipertensi kehamilan khusu yang secara signifikan mempengaruhi morbiditas dan kematian ibu diseluruh dunia. Hal ini terjadi dalam 5-7\% dari seluruh kehamilan, Penyebab utama kematian ibu di negara berkembang. Pre eklamsia juga merupakan factor penting morbiditas dan mortalitas perinatal, karena berhubungan dengan kelahiran premature dan pembatasan pertumbuhan dalam Rahim. Ada beberapa faktor yang dapat mendukung timbulnya pre eklampsia, yang pertama, faktor reproduksi yang terdiri dari: usia, paritas, jarak kehamilan, keturunan dan kehamilan ganda. Yang kedua, faktor status kesehatan yang terdiri dari: riwayat hipertensi, riwayat preeklampsi, riwayat penyakit diabetus militus, status gizi, pengetahuan dan psikologi. Yang ketiga, perilaku sehat diantaranya: antenatal care dan riwayat akseptor KB (Wulandari, 2015).

Berdasarkan data yang diperoleh dari Puskesmas Pasar Kota Prabumulih tahun 2018 didapatkan jumlah ibu yang mengalami pre eklamsia pada saat kehamilan berjumlah 65 orang (Rekam Medik Puskesmas Pasar Kota Prabumulih, 2019). Tingginya kasus pre eklamsi di Puskesmas Pasar kota Prabumulih maka penulis tertarik untuk melakukan penelitian tentang "Hubungan pengetahuan dan status gizi dengan kejadian pre eklamsia pada ibu hamil di Puskesmas Pasar Kota Prabumulih pada tahun 2019"

\section{METODE}

Jenis penelitian ini menggunakan metode Survey Analitik dengan pendekatan Cross Sectional dimana http://jurnalilmiah.stikescitradelima.ac.id/index.php/JI Vol.4,No.1, Juli 2020 
variabel independen dan varibel dependen dikumpulkan dalam waktu yang bersamaan. Sehingga penelitian mengambil variabel independen (pengetahuan dan status gizi) dan variabel dependen (kejadian pre-eklamsia) yang dikumpulkan dalam waktu yang bersamaan (Notoadmojo, 2014).

Populasi penelitian ini yaitu ibu hamil yang mengalami pre eklamsia di Puskesmas Pasar Kota Prabumulih, sampel penelitian adalah seluruh objek yang diteliti (Notoatmodjo, 2014). Pengambilan sampel pada penelitian ini menggunakan metode accidental sampling dengan jumlah sampel sebanyak 58 responden.

Waktu penelitian dilaksanakan pada bulan maretapril 2019. Data yang digunakan pada penelitian ini adalah data primer di pueskesmas pasar kota prabumulih, instrument yang digunakan dalam bentuk kuesioner dengan menggunakan metode wawancara sebagai panduan mengambil data di puskesmas pasar kota prabumulih tahun 2019. Penelitian ini menggunakan analisa univariat dan bivariat.

\section{HASIL DAN PEMBAHASAN}

\section{Hasil Penelitian}

\section{Analisa Univariat}

Tabel 1. Distribusi Frekuensi Responden tentang Pre

$$
\text { Eklamisa. }
$$

\begin{tabular}{ccc}
\hline Pre Eklamsia & Frekuensi & \% \\
\hline Ya & 36 & 62,1 \\
\hline Tidak & 22 & 37,9 \\
\hline Jumlah & $\mathbf{5 8}$ & $\mathbf{1 0 0}$ \\
\hline
\end{tabular}

Dari tabel 1. di atas diketahui bahwa dari 58 responden didapatkan responden yang didiagnosa mengalami kejadian Pre Eklamsia sebanyak 36 responden $(62,1 \%)$ dan yang tidak didiagnosa mengalami kejadian Pre Eklamsia sebanyak 22 responden (37,9\%).
Tabel 2. Distribusi Frekuensi Responden Berdasarkan Pengetahuan Ibu.

\begin{tabular}{ccc}
\hline $\begin{array}{c}\text { Pengetahuan } \\
\text { Ibu }\end{array}$ & Frekuensi & \% \\
\hline Baik & 36 & 62,1 \\
\hline Cukup Baik & 20 & 34,5 \\
\hline Kurang Baik & 2 & 3,4 \\
\hline Jumlah & $\mathbf{5 8}$ & $\mathbf{1 0 0}$ \\
\hline
\end{tabular}

Dari tabel 2. di atas diketahui bahwa dari 58 responden didapatkan bahwa responden yang berpengetahuan baik sebanyak 36 responden $(62,1 \%)$, responden yang berpengetahuan cukup baik sebanyak 20 responden $(34,5 \%)$ dan responden yang berpengetahuan kurang baik sebanyak 2 responden $(3,4 \%)$.

Tabel 3. Distribusi Frekuensi Responden Berdasarkan Status Gizi Ibu.

\begin{tabular}{ccc}
\hline Status Gizi & Frekuensi & \% \\
\hline Baik & 29 & 50,0 \\
\hline Buruk & 29 & 50,0 \\
\hline Jumlah & $\mathbf{5 8}$ & $\mathbf{1 0 0}$ \\
\hline
\end{tabular}

Dari tabel 3. di atas diketahui bahwa dari 58 responden didapatkan bahwa responden yang mengalami status gizi baik sebanyak 29 responden $(50,0 \%)$ dan responden yang mengalami status gizi buruk sebanyak 29 responden $(50,0 \%)$.

\section{Analisa Bivariat}

Tabel 4. Hubungan antara Pengetahuan Ibu dengan Kejadian Pre Eklamsia.

\begin{tabular}{|c|c|c|c|c|c|c|c|}
\hline \multirow{3}{*}{$\begin{array}{c}\text { Pengeta } \\
\text { huan } \\
\text { Ibu }\end{array}$} & \multicolumn{4}{|c|}{$\begin{array}{c}\text { Kejadian Pre } \\
\text { Eklamsia }\end{array}$} & \multirow{2}{*}{\multicolumn{2}{|c|}{ Jumlah }} & \multirow{3}{*}{$\begin{array}{c}P- \\
\text { Value }\end{array}$} \\
\hline & \multicolumn{2}{|c|}{ Ya } & \multicolumn{2}{|c|}{ Tidak } & & & \\
\hline & n & $\%$ & n & $\%$ & $\mathbf{N}$ & $\%$ & \\
\hline Baik & 28 & 48,1 & 8 & 13,8 & 36 & 62,1 & \multirow{4}{*}{0,006} \\
\hline Cukup & 7 & 12,1 & 13 & 22,4 & 20 & 34,5 & \\
\hline Kurang & 1 & 1,7 & 1 & 1,7 & 2 & 3,4 & \\
\hline Jumlah & 36 & 62,1 & 22 & 37,9 & 58 & 100 & \\
\hline
\end{tabular}

http://jurnalilmiah.stikescitradelima.ac.id/index.php/JI Vol.4,No.1, Juli 2020 
Dari tabel 4. di atas dapat dilihat bahwa dari 58 responden didapatkan responden yang didiagnosa mengalami kejadian pre Eklamsia sebanyak 36 responden $(62,1 \%)$ dan yang tidak didiagnosa mengalami kejadian pre eklamsia sebanyak 22 responden $(37,9 \%)$. Dari 36 responden yang berpengetahuan baik terdapat 28 responden $(48,3 \%)$ dengan kejadian pre eklamsia dan 8 $(13,8 \%)$ responden yang tidak mengalami pre eklamsia. Dari 20 responden yang berpengetahuan cukup baik terdapat $7(12,1 \%)$ responden dengan kejadian pre eklamsia dan 13 (22.4\%) responden yang tidak mengalami pre eklamsia. Dari 2 responden yang berpengetahuan kurang baik terdapat $1(1,7 \%)$ responden dengan kejadian pre eklamsia dan $1(1,7 \%)$ responden yang tidak mengalami pre eklamsia.

Berdasarkan hasil analisa bivariat dengan uji statistik mengunakan Chi-Square didapatkan hasil $p$ value $=0,006(p<0,05)$ berarti hipotesis menyatakan bahwa ada hubungan yang bermakna antara Pengetahuan Ibu dengan Kejadian Pre Eklamsia terbukti.

Tabel 5. Hubungan antara Status Gizi dengan Kejadian Pre Eklamsia.

\begin{tabular}{|c|c|c|c|c|c|c|c|}
\hline \multirow{3}{*}{$\begin{array}{c}\text { Status } \\
\text { Gizi }\end{array}$} & \multicolumn{4}{|c|}{$\begin{array}{c}\text { Kejadian Pre } \\
\text { Eklamsia }\end{array}$} & \multirow{2}{*}{\multicolumn{2}{|c|}{ Jumlah }} & \multirow{3}{*}{$\begin{array}{c}P- \\
\text { Value }\end{array}$} \\
\hline & \multicolumn{2}{|c|}{ Ya } & \multicolumn{2}{|c|}{ Tidak } & & & \\
\hline & $\mathbf{n}$ & $\%$ & $\mathbf{n}$ & $\%$ & $\mathbf{N}$ & $\%$ & \\
\hline Baik & 25 & 43,3 & 4 & 6,9 & 29 & 50,0 & \multirow{3}{*}{0,000} \\
\hline Buruk & 11 & 19,0 & 18 & 31,0 & 29 & 50,0 & \\
\hline Jumlah & 36 & 62,1 & 22 & 37,9 & 58 & 100 & \\
\hline
\end{tabular}

Dari tabel 5. di atas dapat dilihat bahwa dari 58 responden didapatkan responden yang didiagnosa mengalami kejadian pre eklamsia sebanyak 36 responden $(62,1 \%)$ dan yang tidak didiagnosa mengalami kejadian pre eklamsia sebanyak 22 responden (37,9\%). Dari 29 responden yang berstatus gizi baik terdapat 25 responden $(43,3 \%)$ dengan kejadian pre eklamsia dan 4 (6,9\%) responden yang tidak mengalami pre eklamsia. Dari 29 responden yang berstatus gizi buruk terdapat $11(19,0 \%)$ responden dengan kejadian pre eklamsia dan 18 (31,0\%) responden yang tidak mengalami pre eklamsia.

Berdasarkan hasil analisa bivariat dengan uji statistik mengunakan Chi-Square didapatkan hasil $p$ value $=0,000(p<0,05)$ berarti hipotesis menyatakan bahwa ada hubungan yang bermakna antara Status Gizi dengan Kejadian pre eklamsia terbukti.

\section{Pembahasan}

\section{Hubungan Pengetahuan Ibu dengan Kejadian Pre Eklamsia.}

Pada penelitian ini variable pengetahuan ibu dikategorikan menjadi 3 kelompok yaitu baik (bila ibu mampu menjawab dengan benar kuisioner 8 sampai 10 pertanyaan mengenai pre eklamsia), cukup baik (bila ibu mampu menjawab dengan benar kuisioner 5-7 pertanyaan) dan kurang baik (bila ibu menjawab dengan benar 1-4 pertanyaan tentang pre eklamsia). Didapatkan bahwa responden yang berpengetahuan baik tentang pre eklamsia sebanyak 28 responden (48,3\%). Hasil uji statistic chi-square di dapatkan $p$ value $=0,006$ maka hipotesis yang mengatakan ada hubungan antara pengetahuan ibu dengan pre eklamsia.

Hal ini sejalan dengan penelitian yang dilakukan oleh Situmorang (2016), menyatakan hasil uji statistic diperoleh nilai $p$ value $=0,00(\mathrm{p}>0,05)$ dapat disimpulkan bahwa ada hubungan yang signifikan antara pengetahuan dengan kejadian pre eklamsia.

Menurut Manuaba (2010), pengetahuan ibu tentang preeklamsia dan eklampsia sangatlah penting karena hampir 50\% kematian ibu dan janin disebabkan oleh pre eklamsia dan eklampsia, sehingga merupakan hal yang penting bagi ibu hamil untuk mengetahui tentang preeklamsia dan eklampsia sedini mungkin.

Berdasarkan penjelasan diatas, bahwa pengetahuan sangat penting bagi kehidupan kita, dan pengetahuan tentang kesehatan dan masalah kesehatan sangat berpengaruh bagi ibu hamil terutama masalah prekelamsia karna preeklamsia dapat mempengaruhi ib

http://jurnalilmiah.stikescitradelima.ac.id/index.php/JI Vol.4,No.1, Juli 2020 
dan janin sehingga dibutuhkan sosialisasi dan informasi mengenai tanda dan gejala preeklamsia agar ibu hamil dapat mendeteksi sedini mungkin dengan demikian berhubungan dengan kejadian pre eklampsia di Puskesmas Pasar Kota Prabumulih.

\section{Hubungan Status Gizi dengan Kejadian Pre Eklamsia.}

Pada penelitian variable status gizi terhadap pre eklampsia dapat dikategorikan menjadi dua kelompok yaitu status gizi baik (bila nilai ukur lingkar lengan diatas $\geq 23,5 \mathrm{~cm}$ ) dan status gizi buruk (bila nilai ukur lingkar lengan $<23,5 \mathrm{~cm})$. responden yang status gizi baik sebanyak 25 responden (43,3\%). Hasil uji statistic chisquare didapatkan nilai $p$ value $=0,000$ maka hipotesis mengatakan ada hubungan status gizi ibu dengan kejadian preeklamsia.

Penelitian ini sejalan dengan penelitian yang dilakukan oleh Wulandary (2013) menyatakan ada hubungan antara status gizi dengan kejadian pre eklamsia pada ibu hamil di Puskesmas Geyer I Kabupaten Grobogan. Hal ini dapat dilihat dengan hasil penelitian dengan nilai $p$ value $=0,003$.

Penelitian ini membuktikan bahwa kondisi berat badan berlebihan atau kegemukan saat kehamilan memperbesar resiko kejadian pre ekalmsia. Kegemukan menyeybabkan kolestrol tinggi dalam darah juga menyebabkan kerja jantung lebih berat. Makin gemuk seseorang makin banyak pula jumlah darah yang terdapat didalam tubuh yang berarti makin berat pula fungsi pemompaan jantung sehingga dapat menyebabkan terjadinya pre eklamsia (Rozikhan, 2007).

Resiko kejadian pre eklamsia dapat dikurangi apabila ibu hamil dapat menjaga pertambahan berat badan sesuai yang dianjurkan. Menurut Soekirman dkk, (2006) pertambahan berat badan yang tepat akan menentukan kesehatan bayi yang akan dilahirkan.

\section{SIMPULAN}

Terdapat hubungan antara pengetahuan denga kejadian pre eklamsia di Pukesmas Pasar Kota Prabumulih $p$-value $(0,006)$.

Terdapat hubungan antara pengetahuan dengan kejadian pre eklamsia di Puskesmas Pasar Kota Prabumulih $p$-value $(0,000)$.

\section{DAFTAR PUSTAKA}

Depkes. RI. (2015). Angka-kematian-bayi menurutWHO-tahun-2015 diakses tangga 23 Maret 2019 pukul 15.30 WIB.

Fatmawati. (2014). hubungan-antara pengetahuandengan-kejadian pre eklamsia-pada-ibu-hamildi-Puskesmas Juwana-Kabupaten-Pati-tahun2014 diaskses tanggal 23 Maret 2019 pukul 15.30WIB

Fang, J., Dawson, A., Lohsoonthorn, V., Williams, M. A. Risk Faktors of Early and Late Onset Preeclampsia among Thai Women. NIH Public Access. Author Manuscript PMC. Asian Biomed (Res Rev News). 2009 October 1; 3(5): 477- 486

Kepmenkes RI. (2018). Angka-kematian-ibu menurutWHO-SDKI-angka-BBLR tahun 2019 diakses tanggal 25 Februari 2019 pukul 15.30 WIB

Lesty. (2018). Angka-kematian-ibu-disumatera-selatan diakses tanggal 5 Februari 2019 pukul 12.00 WIB

Manuaba. (2010). Ilmu Kebidanan Penyakit Kandungan dan Pelayanan Keluarga Berencana. Jakarta: EGC.

Manuaba. (2012). Ilmu Kebidanan Penyakit Kandungan dan Pelayanan Keluarga Berencana. Jakarta: EGC.

Marmi. (2013). Asuhan Patologi Kebidanan. Jakarta: EGC.

Maryunani, Anik dkk. (2012). Asuhan Kegawatdarutan Maternal dan Neonatal. Jakarta: Trans Info Media

http://jurnalilmiah.stikescitradelima.ac.id/index.php/JI Vol.4,No.1, Juli 2020 
Notoadmodjo, Soekidjo. (2014). Metodelogi Penelitian Kesehatan. Jakarta : Renieka Cipta.

Prawiroharjo, Sarwono. (2010). Ilmu Kandungan, Cetakan ke-4. Jakarta : PT Gramedia.

Prawiroharjo, Sarwono.(2012). Ilmu Kandungan, Cetakan ke-4. Jakarta : PT Gramedia

Rekam Medik Puskesmas Pasar Kota Prabumulih. (2018). Profil Puskesmas Pasar Kota Prabumulih 2018 .

Riskesdas. (201). Angka-kematian-bayi tahun-2015 diakses tanggal 2 Januari 2018 pukul 12.30 WIB.

Rohzikhan. (2007). Faktor-faktor resiko terjadinya pre eklamsia berat di rumah sakit Dr. H. Soewondo Kendal. Tesis Program studi magister epidemologi universitas diponegoro semarang, diakses dari http://eprints.undip.ac.id/18342/ROZIKHAN.pdf

Roffihin. (2014). Angka-kematian-ibu menurut-SDKI diakses tanggal 5 Februari 2019 pukul 12.00 WIB

Rukiyah,dkk. (2012). Asuhan Bayi Baru Lahir. Jakarta Trans Info Media.

Siswi, Wulandari. (2015). Hubungan-antara status-gizidengan-kejadian-pre-eklamsia pada-ibu-hamildi-Rumah-Sakit-Aura SyifaKabupatenKediridiakses tanggal 25 Februari 2019 pukul 15.30 WIB.

Wiknjosastro. (2010). Buku Acuan Pelayanan Maternal dan Neonatal. Jakarta : PT. Bina Pustaka Sarwono Prawirohardjo.

WHO. (2015). Angka-kematian-ibu-menurut WHOtahun-2015 diakses tanggal 25 Desember 2017 pukul 15.30 WIB. 